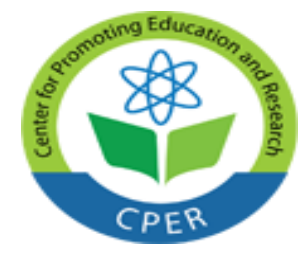

VOL: 1, ISSUE: 9

September/2019

https://ijssppnet.com/

E-ISSN: 2663-7200

(C) Center for Promoting Education and Research (CPER) USA

WWW.cpernet.org

\title{
Effect of Organizational Citizenship Behavior and Compensation to the Performance of Employees Though Organizational Commitment PT. MERAK BETON JAYA CIKARANG
}

\author{
Alpheus Riswanto \\ Student Master of Management \\ Faculty Economics \\ University of Krisnadwipayana \\ Jakarta, Indonesia \\ e-mail: alphaeus2000@gmail.com \\ Abdul Rivai \\ Associate Professor \\ Faculty Economics \\ University of Krisnadwipayana \\ Jakarta, Indonesia \\ e-mail: abdulrivai@unkris.ac.id \\ Suharto \\ Associate Professor \\ Faculty Economics \\ University of Krisnadwipayana \\ Jakarta, Indonesia \\ e-mail: suharto@unkris.ac.id
}

Abstract

This study aims to determine the effect of citizenship organizational behavior and compensation to organizational performance simultaneously, determine the effect of citizenship organizational behavior to organizational performance partially determine the effect of compensation to organizational performance partially determine the effect of organizational commitment on organizational performance partially determine the effect of citizenship organizational behavior on performance through organizational commitment and determine the effect of compensation to organizational performance through organizational commitment variable. The study was conducted on the organization of PT. Merak Beton Jaya Cikarang. Sampling using saturated samples involving 90 employees in all parts of the organization. Analysis of data using path analysis.

Based on data analysis known that variable of organizational citizenship behavior and compensation effect on organizational performance simultaneously. Organizational citizenship behavior variables affect the performance of an organization partially. Variable compensation effect on organizational performance partially. Organizational commitment variables affect the performance of an organization partially. The influence of organizational citizenship behavior and compensation to organizational performance is smaller than through the commitment of the organization of work.

\section{Keywords: Organizational citizenship behavior, compensation, organizational commitment, organizational performance}

\section{Introduction}

Organizational performance of a company is determined by intensity employees and leadership in carrying out the task. The ability of management and employees in synergize duties involved in producing the organization's performance. One factor that also plays a role in enhancing the performance of the organization is the implementation 


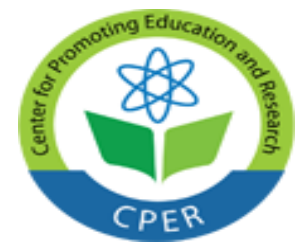

VOL: 1, ISSUE: 9

September/2019

https://ijssppnet.com/

E-ISSN: 2663-7200

\section{(C) Center for Promoting Education and Research (CPER) USA}

WWW.cpernet.org

of organizational citizenship behavior. Organizational citizenship behavior (OCB) is a behavior that is not part of the task that has been formally required for an employee but overall encouraging the effective functioning of the organization (Robbins,2013). In terms of the effectiveness of the organization, individuals in a team need to have behaviors that support. Organizational citizenship behavior(OCB) or also known as organizational citizenship behavior is a behavior in which someone is willing to do anything beyond what has been described by his work, and did not have an appreciation for it. Such behavior is not only appropriate behavior any role but is expected to bring extra-role behavior of the individual so that the fabric can be more solid teamwork and can work optimally for the organization (Bennet in Krishnan 2008). This behavior will impact on organizational performance. Such behavior is not only appropriate behavior any role but is expected to bring extra-role behavior of the individual so that the fabric can be more solid teamwork and can work optimally for the organization (Krishnan 2004). This behavior will impact on organizational performance. Such behavior is not only appropriate behavior any role but is expected to bring extra-role behavior of the individual so that the fabric can be more solid teamwork and can work optimally for the organization (Bennet in Krishnan 2008). This behavior will impact on organizational performance.

Another factor that affects performance is compensated. Compensation according to Hasibuan (2007) is "All income in the form of money, goods directly or indirectly received by employees as a reward for services rendered to the company". While understanding the compensation according to Simamora (2008) is: "What is accepted by the employees in exchange for their contributions to the organization. Arita (2014) states compensation is all the income in the form of money or goods directly or indirectly received by employees in exchange for services provided to the agency.

Wages and salaries are different things. Wages are paid a base which is often used for production workers and maintenance or for daily workers who are not employees or full-time employees. Wages are usually is daily, weekly or monthly following an agreement between the employee and the employer. Salaries generally applicable to the fare paid weekly, monthly, or yearly given regularly.

Organizational commitment also indicated an impact on organizational performance. organizational commitment is a condition in which an employee is favoring a particular organization as well as the goals and desires to retain membership in the organization. Thus, a high job involvement means favoring certain work of an individual, while a high organizational commitment means favoring organizations that recruit such individuals.

\section{Literature Review}

\section{Organizational Citizenship Behavior}

Organizational citizenship behavior (OCB) is a behavior that is not part of the task that has been formally required for an employee but overall encouraging the effective functioning of the organization (Robbins,2013). In terms of the effectiveness of the organization, individuals in a team need to have behaviors that support. Such behavior is not only appropriate behavior only role but is expected to bring extra-role behavior of the individual so that the fabric can be more solid teamwork and can work optimally for the organization (Bennet in Krishnan 2008).

In addition to the above definition (Podsakoff,2000) also provides those five dimensions of organizational citizenship behavior (OCB):

1. Altruism: behaviors that influence helping colleagues in charge.

2. Conscientiousness: behavior that becomes part of the employees who carry out tasks that exceed the minimum requirements.

3. Sportsmanship: the feelings of the employees to refrain from complaints about things that are not preferable. 


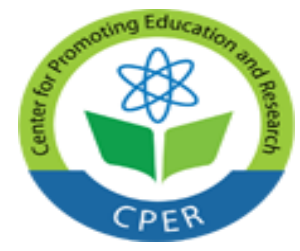

VOL: 1, ISSUE: 9

September/2019

https://ijssppnet.com/

E-ISSN: 2663-7200

\section{(C) Center for Promoting Education and Research (CPER) USA}

WWW.cpernet.org

4. Courtesy: the behavior of the individual parts to replace others in the organization about changes affecting their work.

5. Civic virtue: behavior that becomes part of individuals who indicated that they participate in the company.

The behavior of individuals who freely and spontaneously generated from a person's character or the character of the work or the organization is also derived from the relationship with the boss. This behavior is done to the organization or co-workers, which results in improved organizational effectiveness through the direct influence of the job or the indirect influence of socially-based improvement of interpersonal relationships. Citizenship behavior is not described informal employment, also has no contract awards. OCB indicators include:

1. The nature of Helping

2. Attitude Sport if

3. Fidelity or Loyalty

4. Compliance with the Organization.

OCB is part of organizational behavior. Basic personality traits to reflect OCB employee corporative, helpful, considerate and sincerely. While the basic attitude indicating that the employees involved in the OCB to reply to organizational action (Luthans, 2006: 251).

In Nelson (2012), OCB according to Organ found an extra individual behavior, which is not directly or explicitly recognized in a formal work system, and that in aggregate can improve the effectiveness of the functioning of the organization. Then for the next research OCB formulate deeper, that contribute to the maintenance and improvement of the social and psychological context to support the task.

OCB is a term used to identify an employee's behavior so that he can be termed as a good member. OCB is a favorable form, extra-role behavior to colleagues to help each other, especially their shape. From the definition of the experts, it can be concluded that OCB is extra-role individual behavior towards co-workers can increase the effectiveness of the functioning of the organization. Organizations generally believe that to achieve excellence should seek individual performance as high as basically individual performance affects the performance of the team or workgroup and ultimately affect the overall performance of the organization.

This behavior arises because the feeling as a member of the organization and is satisfied if it can do something more to the organization. Feeling as the members are satisfied when doing a much only happen if employees have a positive perception of the organization. OCB is the act of someone outside obligations, not paying attention to their interest. OCB contribute to the welfare of the community, the transformation of resources, innovation and adaptation and overall organizational performance including increasing the effectiveness and efficiency of the deployment of scarce resources, time and problem solving among working units in a collective way and interdependence.

Such behavior will not be rewarded either directly or sanctions do or not, but the constructive attitude shown by the OCB employee will give a positive assessment (in Nelson,2012). Organizations need employees who joined the behaviors of citizenship are good, such as in statements constructive about working groups and their organizations, helping others in their team, volunteer for additional activities, avoiding unnecessary conflicts, show attention to property organizations, respect the spirit as well as the rules and rule-based, and are willing to tolerate disruption and losses that are associated with precarious employment (Robbins, 2008: 30).

\section{Compensation}

Compensation according to Hasibuan(2007) is: "All income in the form of money, goods directly or indirectly received by employees as a reward for services rendered to the company". While understanding the compensation 


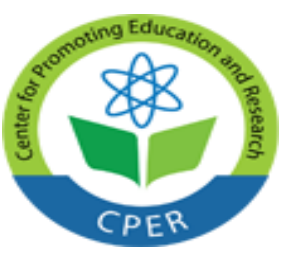

VOL: 1, ISSUE: 9

September/2019

https://ijssppnet.com/

E-ISSN: 2663-7200

\section{(C) Center for Promoting Education and Research (CPER) USA}

WWW.cpernet.org

according to Simamora (2008) is: "What is accepted by the employees in exchange for their contributions to the organization. Arita (2014) states compensation is all the income in the form of money or goods directly or indirectly received by employees in exchange for services provided to the agency.

Notoatmodjo (2009) states that compensation is everything received by employees as remuneration for their work or devotion. Factors that affect the compensation is productivity, ability to pay, willingness to pay, the supply and demand for labor, employee organizations and the rules and regulations. Some things that can be used as an indicator of compensation, according to Simamora (2008) indicators among them are:

\section{1) Wages and Salaries}

Wages and salaries are different things. Wages are paid a base which is often used for production workers and maintenance or for daily workers who are not employees or full-time employees. Wages are usually being daily, weekly or monthly following an agreement between the employee and the employer. Salaries generally applicable to the fare paid weekly, monthly, or yearly given regularly.

\section{2) Incentives}

Is an additional incentive compensation above or beyond the salary or wages provided by the organization? Incentives are usually provided by the company based on their job performance or productivity of employees. Achievement or productivity of employees with good work will receive incentives from the company.

\section{3) Allowance}

Allowances are payments or services provided by the company as a protector or a complement to the basic salary. Examples of benefits are health and life insurance, vacation is borne by the company, pension programs, and other benefits related to the employment relationship.

\section{4) Facility}

Compensation in the form of facilities provided by the company to accelerate and simplify and commitment employee or employee organization in the work. Examples are a pleasure facility such as a company car, club memberships, special parking places, or internet access, work uniforms, and so on.

\section{Organizational Commitment}

According to Robbins and Judge (2008:100) organizational commitment is a condition in which an employee is favoring a particular organization as well as the goals and desires to retain membership in the organization. Thus, a high job involvement means favoring certain work of an individual, while a high organizational commitment means favoring organizations that recruit such individuals.

Meanwhile, according to Moorhead and Griffin (2013:73) organizational commitment is an attitude that reflects the extent to which an individual to know and adhere to the organization. An individual who has committed is likely to see himself as a true member of the organization. Meanwhile, according to Kreitner and Kinicki (2015:165) that reflects the organization's commitment to recognizing the degree to which someone tied to an organization and its goals.

It can be concluded that organizational commitment is a psychological state of individuals associated with faith, trust and a strong reception to the goals and values of the organization, a strong willingness to work for the organization and the degree to which it still wants to be a member of the organization. Robbins and Judge (2008: 101) states that there are three separate dimensions of organizational commitment are: 


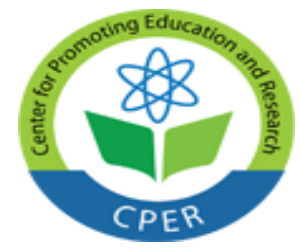

VOL: 1, ISSUE: 9

September/2019

https://ijssppnet.com/

E-ISSN: 2663-7200

\section{(C) Center for Promoting Education and Research (CPER) USA}

WWW.cpernet.org

1. Affective commitment to the organization is an emotional feeling and belief in its values. For example, an employee Petco may have an active commitment to his company because of its involvement with animals.

2. Ongoing commitment is the perceived economic value of surviving in an organization when compared to leaving the organization. An employee may be committed to an employer because he paid them high and that the resignation of the company will destroy his family.

3. Normative commitment is an obligation to stay in an organization for reasons of moral and ethical. For example, an employee who has pioneered a new initiative may survive with an employer because she was leaving someone in a difficult situation when he left.

Organizational commitment is the attitude of the employees who are interested in goals, values and objectives of the organization shown by their acceptance of individuals on the values and goals of the organization and have a desire to affiliate with the organization and a willingness to work hard for the organization to make people feel at home and still want to stay in the organization for the sake of achievement of objectives and survival of the organization.

\section{Organizational Performance}

According to Richard et al (2009), the performance of the organization is generated by an organization that includes the result that financial performance such as profit, as measured by return on assets, return on investment and so on, the performance of markets such as the expansion of market share, and sales. Besides the return of shareholders, a return of shareholders and increase the economy of shareholders.

In some areas of the organization's performance can also be measured by other things such as strategic planning, operations, finance, legal and organizational development. In developing the institution or organization is a necessity to survive in the competitive world climate.

The purpose of productivity associated with the development of that organization (Shrestha,2005). Small organizations that have a desire to continue to grow and become large. The growing organization in order to the development itself.

Besides according to Kaplan and Norton (1992) the organization's performance should be measured in terms of concept not only financial but also from non-financial. Performance can be measured by productivity, quality, consistency and so on. On the other hand, measure organizational performance outcomes, behavioral and normative level, education and concepts generated including management development (Richard, 2010).

\section{Research Methods}

\section{Object of Research}

The study was conducted in PT. Merak Beton Jaya Cikarang.

\section{Population and Sample Research}

The population is a generalization region consisting of the objects/subjects that have a certain quantity and characteristics defined by the researchers to learn and then drawn conclusions (Sugiyono,2013). Samples were towing the majority of the population to represent the entire population (Surakhmad, 2010). The sample used by the author in this study was firm. The total number of employees of 118 people in the area of the organization. Sampling using a saturated sample.

\section{Results and Discussion}


VOL: 1, ISSUE: 9

September/2019

https://ijssppnet.com/

E-ISSN: 2663-7200

(C) Center for Promoting Education and Research (CPER) USA

WWW.cpernet.org

\section{Influence of Organizational Citizenship Behavior and Compensation on Organizational Performance}

Linear analysis model can be based on calculations using SPSS program as follows.

Table 1. Results of Analysis First Equation

\begin{tabular}{|c|c|c|c|c|c|}
\hline \multirow{2}{*}{ Model } & \multicolumn{2}{|c|}{ Unstandardized Coefficients } & Standardized Coefficients & \multirow{2}{*}{$\mathrm{t}$} & \multirow{2}{*}{ Sig. } \\
\hline & $\mathrm{B}$ & Std. Error & beta & & \\
\hline $1 \quad$ (Constant) & 16,500 & 1.949 & & 8.464 &, 000 \\
\hline OCB &, 732 &, 088 & , 476 & 8.290 &, 000 \\
\hline COMPENSATION &, 542 &, 055 &, 569 & 9.916 &, 000 \\
\hline
\end{tabular}

a. Dependent Variable: PERFORMANCE

Based on the tables above, the simultaneous structural equations can be described as follows

$\mathrm{Y}=0,476 \mathrm{X} 1+0,569 \mathrm{X} 2$

Table 2. Calculate the F Value Simultaneous Equations

\begin{tabular}{|c|c|c|c|c|c|c|}
\hline & Model & Sum of Squares & df & mean Square & $\mathrm{F}$ & Sig. \\
\hline \multirow[t]{3}{*}{1} & Regression & 2431.362 & 2 & 1215.681 & 97.333 &, $000 \mathrm{~b}$ \\
\hline & Residual & 1436.341 & 115 & 12.490 & & \\
\hline & Total & 3867.703 & 117 & & & \\
\hline
\end{tabular}

a. Dependent Variable: PERFORMANCE

b. Predictors: (Constant), COMPENSATION, OCB

Based on the above table it is known that calculated $\mathrm{F}$ value of 97.333 and significance of 0.00 . This value is less than 0.05. This means that the variable organizational citizenship behavior and compensation effect on organizational performance simultaneously. The magnitude of the effect of the independent variable on the dependent variable can be seen from the following values of $r$ squared.

Table 3. Rated R Squares Regression Model First

\begin{tabular}{|l|r|r|r|r|r|}
\hline Model & $\mathrm{R}$ & R Square & Adjusted R Square & $\begin{array}{c}\text { Std. Error of the } \\
\text { Estimate }\end{array}$ & Durbin-Watson \\
\hline 1 &, $793 \mathrm{a}$ &, 629 &, 622 & 3.53411 & 1,389 \\
\hline
\end{tabular}

a. Predictors: (Constant), COMPENSATION, OCB

b. Dependent Variable: PERFORMANCE

Based on the above table it is known that the value of $\mathrm{r}$ squared of $62.9 \%$ means that variable organizational citizenship behavior and compensation effect on organizational performance by $62.9 \%$ while the rest influenced by other variables that are not incorporated into the model equations.

\section{Influence Analysis of Organizational Citizenship Behavior on Organizational Performance}

The results of the analysis of the influence of organizational citizenship behavior on organizational performance can be partially seen in the following table.

Table 4. Results of regression equation analysis Second

\begin{tabular}{|l|c|c|c|c|c|}
\hline \multirow{2}{*}{ Model } & \multicolumn{2}{|c|}{ Unstandardized Coefficients } & Standardized Coefficients & \multirow{2}{*}{$\mathrm{t}$} & \multirow{2}{*}{ Sig. } \\
\cline { 2 - 5 } & B & Std. Error & beta & & \\
\cline { 2 - 5 }
\end{tabular}


(C) Center for Promoting Education and Research (CPER) USA

\begin{tabular}{|ll|r|r|r|r|r|}
\hline 1 (Constant) & 25.676 & 2,327 & & 11.035 &, 000 \\
& OCB &, 858 &, 118 &, 558 & 7.238 &, 000 \\
\hline
\end{tabular}

a. Dependent Variable: PERFORMANCE

Structural equation of the above data can be seen as follows $\mathrm{Y}=0,558 \mathrm{X} 1$

Based on the chart above analysis it is known that the coefficient of organizational citizenship behavior amounted to 0.558 . $T$ value of 7.238. The significant value of 0.00 . The significance value smaller than 0.05 . This means that the variable of organizational citizenship behaviors affects the organization's performance partially. The magnitude of the effect of organizational citizenship behavior on organizational performance can be seen in the following table.

Table 5. The value of $r$ Quadratic Equations Second

\begin{tabular}{|r|r|r|r|r|}
\hline \multicolumn{1}{|c|}{ Model } & $\mathrm{R}$ & \multicolumn{1}{c|}{ R Square } & Adjusted R Square & $\begin{array}{c}\text { Std. Error of the } \\
\text { Estimate }\end{array}$ \\
\hline 1 &, $558 \mathrm{a}$ &, 311 &, 305 & 4.79254 \\
\hline
\end{tabular}

a. Predictors: (Constant), OCB

Based on the above table it can be seen $r$ squared value of 0.311 . This means that the influence of organizational citizenship behavior variables on the performance of $31.1 \%$ and the rest influenced by other variables not included in the model equations.

\section{Effect of Analysis Compensation on Organizational Performance}

The analysis results in partial compensation for the performance can be seen in the following table.

Table 6. Analysis Third Regression Equations

\begin{tabular}{|cc|c|c|c|c|c|}
\hline \multirow{2}{*}{ Model } & \multicolumn{2}{|c|}{ Unstandardized Coefficients } & Standardized Coefficients & \multirow{2}{*}{$\mathrm{t}$} & \multirow{2}{*}{ Sig. } \\
\cline { 3 - 5 } & & $\mathrm{B}$ & Std. Error & beta & & \\
\hline 1 & (Constant) & 29.220 & 1,513 & & 19.307 &, 000 \\
& COMPENSATION &, 607 &, 068 &, 638 & 8.917 &, 000 \\
\hline
\end{tabular}

a. Dependent Variable: PERFORMANCE

Structural equation of the above data can be seen as follows $\mathrm{Y}=0,638 \mathrm{X} 2$

Based on the chart above analysis in mind that the compensation coefficient of 0.638 . $\mathrm{T}$ value of 8.917. The significant value of 0.00 . The significance value smaller than 0.05 . This means that the compensation variables affect the performance of an organization partially. The magnitude of the effect of compensation to organizational performance can be seen in the following table.

Table 7. Value Quadratic Equations r Third

\begin{tabular}{|l|r|r|r|r|}
\hline Model & $\mathrm{R}$ & \multicolumn{1}{c|}{ R Square } & Adjusted R Square & $\begin{array}{c}\text { Std. Error of the } \\
\text { Estimate }\end{array}$ \\
\hline 1 &, $638 \mathrm{a}$ &, 407 &, 402 & 4.44766 \\
\hline
\end{tabular}

a. Predictors: (Constant), COMPENSATION

Based on the above table it can be seen $r$ squared value of 0.407 . This means that the effect of variable compensation to an organizational performance by $40.7 \%$ and the rest influenced by other variables not included in the model equations.

\section{Influence Analysis of Organizational Commitment to Organizational Performance}


VOL: 1, ISSUE: 9

September/2019

https://ijssppnet.com/

E-ISSN: 2663-7200

CCenter for Promoting Education and Research (CPER) USA

WWW.cpernet.org

The analysis results on the performance of organizational commitment partially work can be seen in the following table.

Table 8. Results of regression equation analysis Fourth

Coefficientsa

\begin{tabular}{|c|c|c|c|c|c|}
\hline \multirow{2}{*}{ Model } & \multicolumn{2}{|c|}{ Unstandardized Coefficients } & \multirow{2}{*}{$\frac{\text { Standardized Coefficients }}{\text { beta }}$} & & \multirow{2}{*}{ Sig. } \\
\hline & B & Std. Error & & & \\
\hline 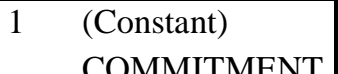 & $\begin{array}{r}9.791 \\
783\end{array}$ & 1,733 & 869 & $\begin{array}{r}5.648 \\
18922\end{array}$ &, 000 \\
\hline
\end{tabular}

a. Dependent Variable: PERFORMANCE

Structural equation of the above data can be seen as follows $\mathrm{Y}=0,869 \mathrm{X} 3$

Based on the chart above analysis it is known that the coefficient of organizational commitment at 0.869 . $T$ value of 18.922 . The significant value of 0.00 . The significance value smaller than 0.05 . This means that the organizational commitment variables affect the performance of an organization partially. The magnitude of the effect of organizational commitment on organizational performance can be seen in the following table.

Table 9. Value Quadratic Equations r Fourth

\begin{tabular}{|c|r|r|r|r|}
\hline Model & $\mathrm{R}$ & R Square & Adjusted R Square & $\begin{array}{c}\text { Std. Error of the } \\
\text { Estimate }\end{array}$ \\
\hline 1 &, $869 \mathrm{a}$ &, 755 &, 753 & 2.85642 \\
\hline
\end{tabular}

a. Predictors: (Constant), COMMITMENT

Based on the above table it can be seen $r$ squared value of 0.755 . This means that the effect of variable organizational commitment to organizational performance amounted to $75.5 \%$ and the rest influenced by other variables not included in the model equations.

\section{Organizational Citizenship Behavior Analysis of Effect on Organizational Performance Through Organizational Commitment}

Based on the partial path analysis above, it can be described as follows. The analysis is an analysis online with the structure of this sub-image.

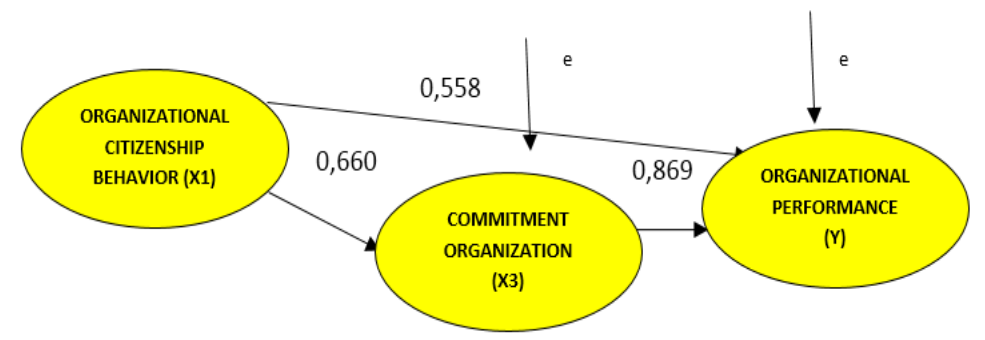

Figure 1. Analysis of the influence lines X1 to Y via X3

Table 10. Effects of Organizational Citizenship Behavior Organizational Through Commitment

\begin{tabular}{|c|c|c|c|c|c|}
\hline \multirow[b]{2}{*}{ Model } & \multicolumn{2}{|c|}{ Unstandardized Coefficients } & \multirow{2}{*}{$\frac{\text { Standardized Coefficients }}{\text { beta }}$} & \multirow[b]{2}{*}{$t$} & \multirow[b]{2}{*}{ Sig. } \\
\hline & $\mathrm{B}$ & Std. Error & & & \\
\hline 1 (Constant) & 19.701 & 2.339 & & 8.423 &, 000 \\
\hline OCB & 1.127 &, 119 & 660 & 9.459 & 000 \\
\hline
\end{tabular}

a. Dependent Variable: COMMITMENT 


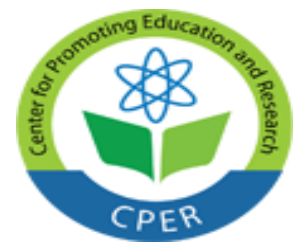

VOL: 1, ISSUE: 9

September/2019

https://ijssppnet.com/

E-ISSN: 2663-7200

\section{(C) Center for Promoting Education and Research (CPER) USA}

WWW.cpernet.org

Based on the picture above can be seen that the influence of organizational citizenship behavior on organizational performance is 0.558. Organizational citizenship behavior influence on performance through organizational commitment is $0.660 \times 0.869=0.5676$. In this case, the indirect effect is greater than the direct effect so that it can be said that the work organization commitment variable as an intervening variable.

\section{Effect of Analysis Compensation on Organizational Performance Through Organizational Commitment}

Based on the partial path analysis above, it can be described as follows. The analysis is an analysis online with the structure of this sub-image.

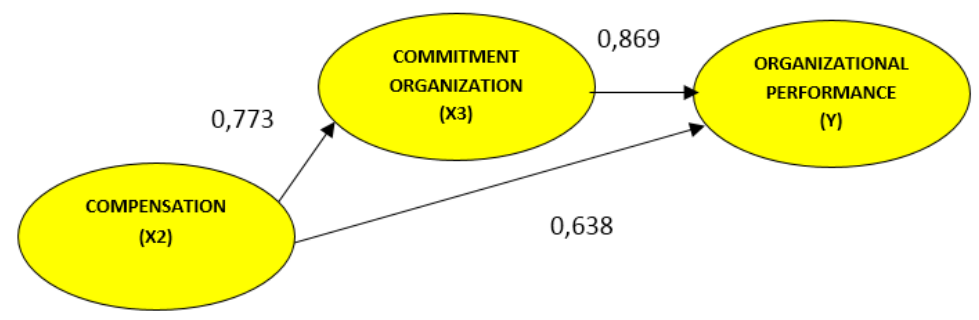

Figure 2. Analysis of the influence lines X2 to Y via

Table 11. Coefficient Values Compensation Effect to Commitment

\begin{tabular}{|c|c|c|c|c|c|}
\hline \multirow{2}{*}{ Model } & \multicolumn{2}{|c|}{ Unstandardized Coefficients } & \multirow{2}{*}{\begin{tabular}{|c|} 
Standardized Coefficients \\
beta
\end{tabular}} & \multirow{2}{*}{$\mathrm{t}$} & \multirow{2}{*}{ Sig. } \\
\hline & $\mathrm{B}$ & Std. Error & & & \\
\hline $\begin{array}{ll}1 & \text { (Constant) } \\
& \text { COMPENSATION }\end{array}$ & $\begin{array}{r}23.936 \\
, 817\end{array}$ & $\begin{array}{r}1,384 \\
, 062\end{array}$ &, 773 & $\begin{array}{l}17.296 \\
13.126\end{array}$ & $\begin{array}{l}, 000 \\
, 000\end{array}$ \\
\hline
\end{tabular}

a. Dependent Variable: COMMITMENT

Based on the picture above it can be seen that the direct effect of compensation to organizational performance is 0.638 . Whereas compensation to organizational performance through organizational commitment is $0.773 \times 0.869$ $=0.671$. In this case smaller than the direct influence indirect influence so that it can be said that the work organization commitment variable as an intervening variable.

\section{Conclusions and Suggestions}

\section{Conclusion}

Variable organizational citizenship behavior and compensation effect on organizational performance simultaneously. $\mathrm{F}$ value calculated at 97.333 and significance of 0.00 . This value is less than 0.05 . R squared value of $62.9 \%$ means that variable organizational citizenship behavior and compensation effect on organizational performance by $62.9 \%$ while the rest influenced by other variables that are not incorporated into the model equations.

Organizational citizenship behavior variables affect the performance of an organization partially. $\mathrm{T}$ value of 7.238. The significant value of 0.00 . The significance value smaller than 0.05 . R squared value of 0.311 . This means that the influence of organizational citizenship behavior variables on the performance of $31.1 \%$ and the rest influenced by other variables not included in the model equations.

Variable compensation effect on organizational performance partially. T value of 8.917. The significant value of 0.00 . The significance value smaller than 0.05 . R squared value of 0.407 . This means that the effect of variable compensation to the organizational performance by $40.7 \%$ and the rest influenced by other variables not included in the model equations.

Organizational commitment variables affect the performance of an organization partially. T value of 18.922 . The significant value of 0.00 . The significance value smaller than 0.05 . $R$ squared value of 0.755 . This means that the 


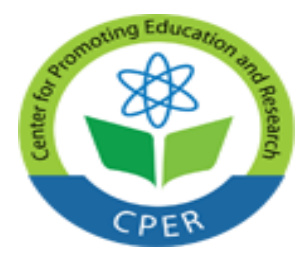

VOL: 1, ISSUE: 9

September/2019

https://ijssppnet.com/

E-ISSN: 2663-7200

\section{(C) Center for Promoting Education and Research (CPER) USA}

WWW.cpernet.org

effect of variable organizational commitment to organizational performance amounted to $75.5 \%$ and the rest influenced by other variables not included in the model equations.

The influence of organizational citizenship behavior on organizational performance is .558. Organizational citizenship behavior influence on performance through compensation is $0,660 \times 0,869=0.5676$. In this case, the indirect effect is greater than the direct effect so that it can be said that the work organization commitment variable as an intervening variable.

The direct effect of compensation to organizational performance is 0,638 . While the effect of compensation to organizational performance through organizational commitment is $0,773 \times 0,869=0.671$. In this case smaller than the direct influence indirect influence so that it can be said that the work organization commitment variable as an intervening variable.

\section{Suggestion}

Organizational citizenship behavior (OCB) is a behavior that is not part of the task that has been formally required for an employee but overall encouraging the effective functioning of the organization. The behavior can be improved by taking into account the attitude of altruism (happy to help) co-workers, conscientiousness attitude (being part of the work), Sportsmanship attitude (attitude did not complain), the attitude of courtesy (could replace the role) and civic (can participate).

Compensation under Hasibuan (2005) is: "all income in the form of money, goods directly or indirectly received by employees as a reward for services rendered to the company. It also needs to be considered by the organization staff salaries and other payments that are non-financial.

Organizational commitment is a condition in which an employee is favoring a particular organization as well as the goals and desires to retain membership in the organization. Increased commitment can be made through affective commitment, continuous commitment, and normative commitment.

\section{References}

Arita, S., Pan, M., dan Leung, P. 2014. The Distributive Economic Impacts of Hawaii's Commercial Fishery: A SAM Analysis. Fishers Research, 145:82-89.

Daft, Richard L. 2010. Manajemen Edisi Kelima Jilid Satu. Jakarta : Erlangga.

Fred Luthans. 2000. Perilaku Organisasi - Edisi Sepuluh, Penerbit Andi, Yogyakarta.

Kaplan, R. S., \& Norton, D. P. 1992. The Balanced Scorecard - Measures that Drive Performance. Harvard Business Review.

Kreitner dan Kinicki, 2015, Organizational Behavior . 8 th Edition . Boston : McGraw-Hill.

Krishnan, V.R. 2004. Impact of transformational leadership on followers' influence strategies. The Leadership \& Organization Development Journal. Vol. 25 No. 1. 58-72.

Moorhead, Gregory dan Ricky W. Griffin. 2013. Perilaku Organisasi. Jakarta: Salemba Empat.

Nelson, D.L \& Quick, J.C. 2012. Organizatonal Behavior Foundations Realities and Challenges. Thompson South Western. United States of America.

Podsakoff, P.M., Ahearne, M., \& McKenzie, S.B. 1997.Organizational Citizenship Behaviour and The Quantity and Quantity of Work Group Performance. Journal of Applied Psychology, Vol. 82: 262-270. 
